\title{
LAW APPLICABLE TO CLOUD COMPUTING CONTRACTS CONCLUDED WITH CONSUMERS UNDER REGULATION 593/2008, ACCORDING TO THE CJEU CASE LAW*
}

by

KRZYSZTOF $\dot{Z} O K^{* *}$

The undoubted popularity of cloud computing stems in particular from the fact that the provider can simultaneously offer access to his or her computing resources to an almost unlimited number of users located in different countries. Although this feature brings significant benefits to the provider, it also raises serious questions regarding the law governing the contract. The concerns become especially relevant in the case of contracts concluded between a consumer and a professional due to the limits of the choice of law and the special rules protecting consumers.

The article analyses the law applicable to cloud computing contracts concluded with consumers. The considerations focus on the special provisions regarding consumer protection. Contrary to some comments, the article claims that the current legal framework is sufficient to determine the applicable law, although this task is not without doubts.

\section{KEY WORDS}

Applicable Law, Cloud Computing, Contract Law, International Private Law

\section{THE UBIQUITY OF CLOUD COMPUTING}

Cloud computing has become commonly used in many areas of everyday life. Despite its popularity, this IT solution has yet not been defined in legal

\footnotetext{
The article is the result of the research grant No. 2015/19/D/HS5/00006 funded by National Science Centre, Poland.

** krzysztof.zok@amu.edu.pl; Faculty of Law and Administration, Adam Mickiewicz University in Poznań, Poland.
} 
acts recognized at the European or international level. However, the gap can be filled by the recommendations of the National Institute of Standards and Technology, an agency of the US Department of Commerce. ${ }^{1}$ The recommendations define the term "cloud computing" as

"a model for enabling ubiquitous, convenient, on-demand network access to a shared pool of configurable computing resources (e.g. networks, servers, storage, applications, and services) that can be rapidly provisioned and released with minimal management effort or service provider interaction." ${ }^{2}$

It is worth noting that "ubiquity" begins the list of characteristics of cloud computing. Although the term is not further explained, the recommendations justify the assumption that it refers to the ability to access the cloud at any time and place by an almost unlimited number of users. More importantly, mentioning ubiquity as the first feature of that IT solution is not entirely accidental. From the user's perspective, this characteristic translates into convenient access to provider's computing resources. It should also be noted that the fee paid by the user firstly covers the cost of establishing the cloud infrastructure. Then, the rest of the fee generates the provider's income. Moreover, the cost of establishing the infrastructure is relatively fixed. Therefore, when more and more users are paying for the cloud, the part of the fee constituting the provider's income is growing at a faster pace. This stems from the fact that the relatively fixed costs related to the infrastructure are shared among an increasing number of users. Consequently, the ubiquity of the clouds also offers significant benefits for the provider, enabling them to achieve economies of scale. It should also be emphasized that the rapidly growing online communication creates a demand for cloud computing. Nevertheless, establishing a robust infrastructure is often expensive. As the result, people interested in using the clouds usually have to rely on third parties, i.e.cloud service providers. The ubiquity of cloud computing is thus arguably one of the main reasons for the popularity of this IT solution.

\footnotetext{
Mell, P. and Grance, T. (2011) The NIST Definition of Cloud Computing. Recommendations of the National Institute of Standards and Technology. [online] Gaithersburg: National Institute of Standards and Technology. Available from: https://nvlpubs.nist.gov/nistpubs/Legacy/SP/ nistspecialpublication800-145.pdf [Accessed 13 January 2020].

2 Ibid.
} 
From the legal point of view, the feature allows the provider to easily enter into contracts with users from various countries. The provider can thereby reduce the period in which the cloud is not working at its full potential. However, the ubiquity of cloud computing also exposes the provider to the risk of simultaneously applying multiple legal systems to essentially the same contract. ${ }^{3}$ Therefore, the provider also faces the risk of not being able to dynamically comply with the requirements of different legal systems. As a result, the question of the law applicable to cloud computing contracts may often arise, especially in the context of consumer contracts due to the special rules of consumer protection and the mass nature of these agreements. The uncertainty as to the law governing the contract is not insignificant given the broad use of cloud computing.

According to some scholars, the issue does not present serious problems because the existing legal framework sufficiently determines the law governing cloud computing contracts. ${ }^{4}$ However, this stance is not unanimously shared. Some scholars claim that determining the law applicable to cloud computing contracts is often difficult. ${ }^{5}$ Others argue that the current legal analysis is not keeping pace with the rapid development of the discussed IT solution. ${ }^{6}$ This may, in turn, translate into difficulties in determining the law applicable to these agreements. It is also claimed that the framework of international private law is no longer adequate for cloud computing contracts. ${ }^{7}$ However, it should be noted that the above comments are often general.

In my opinion, these reservations are not fully convincing. The paper argues that the existing legal framework suffices to determine the law applicable to cloud computing contracts concluded with consumers.

3 Castro, C., Reed, Ch. and de Queiroz, R. (2013) On the Applicability of the Common European Sales Law to Some Models of Cloud Computing Services. European Journal of Law and Technology, 4 (3). Available from: http://ejlt.org/article/view/186/409

[Accessed 13 January 2020].

4 Haibach, G. (2015) Cloud computing and European Union private international law. Journal of Private International Law, 11 (2), p. 262.

5 De Filippi, P. and McCarthy, S. (2012) Cloud Computing: Centralization and Data Sovereignty. European Journal of Law and Technology, 3 (2). Available from: http://ejlt.org/ article/view/101 [Accessed 13 January 2020]; De Filippi, P. and Belli, L. (2012) Law of the Cloud v Law of the Land: Challenges and Opportunities for Innovation. European Journal of Law and Technology, 3 (2). Available from: http://ejlt.org/article/view/156 [Accessed 13 January 2020].

6 Andrews, C.D. and Newman, J.M. (2013) Personal Jurisdiction and Choice of Law in the Cloud. Maryland Law Review, 73, p. 315.

7 Celestine, C.M. (2013) "Cloudy" Skies, Bright Futures? In Defense of a Private Regulatory Scheme for Policing Cloud Computing. Journal of Law, Technology E Policy, 1, p. 152. 
However, this task is not without doubts. The difficulties concern in particular the question of determining if the provider demonstrated the intention to enter into a contract with the consumer domiciled in a specific country. Therefore, the paper focuses on the special provisions regarding the law applicable to consumer contracts. It examines the choice of law and the general provisions concerning the law which governs the contract only to the extent that is necessary for the above analysis.

\section{DETERMINING THE APPLICABLE LAW}

\subsection{THE CHOICE OF LAW AND ITS LIMITS}

The provider usually offers standard terms, especially if the contract is concluded with the consumer. ${ }^{8}$ The provider thus reduces the risks associated with the simultaneous performance of different obligations. The global nature of clouds, however, undermines this strategy. At first sight, the risk can easily be avoided by choosing the law applicable to the agreement, particularly the law of the country where the provider is established. Indeed, empirical studies confirm that cloud computing contracts often specify the law which governs them. ${ }^{9}$ Nevertheless, the choice of law does not dispel all doubts. The applicable law provided for in the contract may adversely affect the user's situation. In particular, it may weaken the protection enjoyed by the consumer under his or her domestic law. Moreover, the user may not be familiar with the law specified in the contract.

Therefore, it should be emphasized that European law protects consumers not only through substantive law, but also through international private law. The protection also applies if a choice of law has been made. According to Article 3(1) of Regulation 593/2008, the choice must be made expressly or clearly demonstrated by the terms of the contract

\footnotetext{
Bradshaw, S., Millard, Ch. and Walden, I. (2011) Contracts for Clouds: Comparison and Analysis of the Terms and Conditions of Cloud Computing Services. International Journal of Information Technology and Law, 19 (3), pp. 188-189; Irion, K. (2015) Your Digital Home is No Longer Your Castle: How Cloud Computing Transforms the (Legal) Relationship Between Individuals and Their Personal Records. International Journal of Law and Information Technology, 23, p. 358.

9 Bradshaw, S., Millard, Ch. and Walden, I. (2011) Contracts for Clouds: Comparison and Analysis of the Terms and Conditions of Cloud Computing Services. International Journal of Information Technology and Law, 19 (3), pp. 198-199; Haibach, G. (2015) Cloud computing and European Union private international law. Journal of Private International Law, 11 (2), p. 259.
} 
or the circumstances of the case. ${ }^{10}$ The analysis of this provision lies beyond the scope of the current considerations as it would exceed volume limits of this paper. However, it should be noted that failure to meet the requirements set in Article 3(1) of Regulation 593/2008 precludes the application of the chosen law to the contract. Furthermore, the choice of law may be considered unenforceable under Directive 93/13. ${ }^{11}$ There is, of course, no abstract answer to the question whether the choice of law for a particular cloud computing contract is legally binding. ${ }^{12}$ Nevertheless, such situations cannot be completely ignored. Consequently, if the parties do not make a legally binding choice of law, the law governing the contract is determined by Article 6(1) of Regulation 593/2008 which contains a special rule for consumer contracts. Only if this provision cannot also be applied, the applicable law is determined on the basis of the general rules in Article 4 of the Regulation. The conclusion also covers a situation in which the choice of law is void.

Moreover, even if the choice of law is effective, according to Article 6(2) of Regulation 593/2008, the applicable law specified in the contract cannot deprive the consumer of the protection afforded to him or her by the provisions which cannot be derogate from by agreement by virtue of the law which would have been applicable based on Article 6(1) of the Regulation. The provider may, therefore, be often unable to fully subject the contract to the law which they considers the most appropriate. It can even be expected that at least some of the obligations will be determined by the law applicable under Article 6(1) of Regulation $593 / 2008 .{ }^{13}$ Consequently, it is claimed that many contractual provisions drawn by the providers established in the USA may not be legally binding

10 Regulation (EC) No 593/2008 of the European Parliament and of the Council of 17 June 2008 on the law applicable to contractual obligations (Rome I). Official Journal of the European Union (2008/177-L/6), 4 July. Available from: http://data.europa.eu/eli/reg/2008/593/oj [Accessed 13 January 2020].

11 Council Directive 93/13/EEC of 5 April 1993 on unfair terms in consumer contracts. Official Journal of the European Communities (1993/95-L-29), 21 April. Available from: http://data. europa.eu/eli/dir/1993/13/oj [Accessed 13 January 2020].

12 Wauters, E., Lievens, E. and Valcke, P. (2014) Towards a Better Protection of Social Media Users: a Legal Perspective on the Terms of Use of Social Networking Sites. International Journal of Law and Information Technology, 22, p. 278.

13 Castro, C., Reed, Ch. and de Queiroz, R. (2013) On the Applicability of the Common European Sales Law to some Models of Cloud Computing Services. European Journal of Law and Technology, 4 (3). Available from: http://ejlt.org/article/view/186/409 [Accessed 13 January 2020]; Irion, K. (2015) Your Digital Home is No Longer Your Castle: How Cloud Computing Transforms the (Legal) Relationship Between Individuals and Their Personal Records. International Journal of Law and Information Technology, 23, pp. 367-368. 
for consumers domiciled in the European Union. ${ }^{14}$ This conclusion is also supported by the recent judgments in which the Court of Justice of the European Union decided that the lack of information about the law applicable under Article 6(2) of Regulation 593/2008, which causes consumer's error about the provisions which cannot be derogated from by agreement, may be an unfair term within the meaning of Article 3 of Directive 93/13. ${ }^{15}$

From this perspective, it can be argued that the choice of law is more relevant for small-to-medium entrepreneurs than for consumers, who enjoy the protection under European law. ${ }^{16}$ The above considerations also clearly illustrate the importance of determining the law applicable to cloud computing contracts based on Article 6(1) of Regulation 593/2008. The law specified in this provision may often set the minimum standards of consumer protection or even govern the contract.

\subsection{THE LAW OF THE COUNTRY WHERE THE CONSUMER IS DOMICILED}

Pursuant to Article 6(1) of Regulation 593/2008, if the parties do not choose the applicable law, the contract concluded between a consumer and a professional is governed by the law of the country where the consumer has his or her habitual residence, given that other requirements set in this provision are met. In contrast to the general rules, Article 6(1) of the Regulation does not refer to the classification of the contracts. The difference is, however, irrelevant since under Articles 4(1)(b) and 4(2) thereof the contract would be governed by the law of country of the provider's domicile regardless of its qualification.

Besides, as pointed in Recitals 7 and 24 of Regulation 593/2008, Article 6(1) thereof is closely linked to Article 15(1)(c) of Regulation

14 McGillivray, K. (2016) A Right Too Far? Requiring Cloud Service Providers to Deliver Adequate Data Security to Consumers. International Journal of Law and Information Technology, 25, p. 7; Rustad, M.L. and Onufario, M.V. (2012) Reconceptualizing Consumer Terms of Use for a Globalized Knowledge Economy. University of Pennsylvania Journal of Business Law, 14 (4), p. 1116.

15 See judgment of 28 July 2016, Verein für Konsumenteninformation v. Amazon EU Sàrl, C-191/15, EU:C:2016:612; judgment of 3 October 2019, Verein für Konsumenteninformation v. TVP Treuhand- und Verwaltungsgeselleschaft für Publikumsfonds mbH \& Co KG, EU:C:2019:827.

16 Bradshaw, S., Millard, Ch. and Walden, I. (2011) Contracts for Clouds: Comparison and Analysis of the Terms and Conditions of Cloud Computing Services. International Journal of Information Technology and Law, 19 (3), p. 198. 
44/2001 ${ }^{17}$ which was replaced by Article 17(1)(c) of Regulation 1215/2012. ${ }^{18}$ The above provisions undoubtedly aim to improve consumer protection, especially in the case of contracts concluded over the Internet. ${ }^{19}$ Therefore, they take precedence over the general rules. As a result, the Court of Justice of the European Union repeatedly stressed that Article 15(1)(c) of Regulation $44 / 2001$, as an exception, should be interpreted strictly. ${ }^{20}$ Although this stance only refers to the provision of Regulation 44/2001, it remains valid in the context of Article 6(1) of Regulation 593/2008 and Article 17(1)(c) of Regulation 1215/2012 due to the link described above.

From this point of view, the correct interpretation of Article 6(1) of Regulation 593/2008 is crucial. The application of this provision depends on two requirements. Firstly, the professional must pursue his or her commercial or professional activities in the country where the consumer is domiciled. Alternatively, the professional has to direct the activities to that country. Secondly, the contract should fall within the scope of the professional's activities. The latter requirement does not raise important legal questions related to cloud computing contracts. Doubts may, however, concern the fulfilment of the first requirement which consists of two alternative conditions.

\section{PURSUING THE PROFESSIONAL'S ACTIVITIES}

According to Article 6(1)(a) of Regulation 593/2008, the contract is governed by the law of the country where the consumer is domiciled if the professional pursues his or her commercial or professional activities in that country. The wording of this provision is clear. However, the question arises about the significance of Article 6(1)(a) of Regulation

17 Council Regulation (EC) No 44/2001 of 22 December 2000 on jurisdiction and the recognition and enforcement of judgments in civil and commercial matters. Official Journal of the European Union (2001/12-L/1), 16 January. Available from: http://data.europa.eu /eli/reg/2001/44/oj [Accessed 13 January 2020].

18 Regulation (EU) No 1215/2012 of the European Parliament and of the Council of 12 December 2012 on jurisdiction and the recognition and enforcement of judgments in civil and commercial matters (recast). Official Journal of the European Union (2012/351-L/1), 20 December. Available from: http://data.europa.eu/eli/reg/2012/1215/2015-02-26 [Accessed 13 January 2020].

19 For such an interpretation of Article 15(1)(c) of Regulation 44/2001, see e.g. Ilsinger (2009) C-180/06, EU:C:2009:303, paragraph 50, 14 May; Mühlleitner (2012) C-190/11, EU:C:2012:542, paragraph 29, 6 September; Emrek (2013) C-218/12, EU:C:2013:666, paragraph 24, 17 October.

20 Mühlleitner (2012) C-190/11, EU:C:2012:542, paragraph 27, 6 September; Česká spořitelna (2013), C-419/11, EU:C:2013:165, paragraph 26, 14 March; Kolassa (2015), C-375/13, EU:C: 2015:37, paragraph 28, 28 January; Schrems (2018), C-498/16, EU:C:2018:37, paragraph 45, 25 January. 
593/2008 for cloud computing contracts. Empirical studies indicate that providers often choose a law of a particular state in the USA. ${ }^{21}$ As a result, it can be argued that Article 6(1)(a) of Regulation 593/2008 rarely applies to cloud computing contracts concluded with consumers domiciled in the European Union, since the providers generally do not pursue their activities in the Member States.

Indeed, the above provision seems to be of lesser significance in comparison to Article 6(1)(b) of Regulation 593/2008. Because of the ubiquity, the pursuit of the activities in a certain country is not essential for the conclusion and performance of cloud computing contracts concluded with the consumer domiciled in that country. Nevertheless, in my opinion, Article 6(1)(a) of Regulation 593/2008 is not entirely without significance in the case of cloud computing contracts. Several major companies on the cloud market have their local offices in selected countries of the European Union. For example, Microsoft offices operate in all Member State, ${ }^{22}$ Google offices - in 13 Member States, ${ }^{23}$ Spotify offices - in 11 Member States $^{24}$ and Dropbox offices - in 4 Member States. ${ }^{25}$ Therefore, at least some providers pursue their activities in the country of the consumer's domicile. Consequently, Article 6(1)(a) of Regulation 593/2008 may apply to cloud computing contracts. This, however, does not change the fact that not all consumers are covered by the above provision, since the providers do not always operate in the country where the consumer has his or her habitual residence.

${ }^{21}$ Castro, C., Reed, Ch. and de Queiroz, R. (2013) On the Applicability of the Common European Sales Law to some Models of Cloud Computing Services. European Journal of Law and Technology, 4(3). Available from: http://ejlt.org/article/view/186/409 [Accessed 13 January 2020]; Haibach, G. (2015) Cloud computing and European Union private international law. Journal of Private International Law, 11 (2), pp. 255, 263 and 266; Irion, K. (2015) Your Digital Home is No Longer Your Castle: How Cloud Computing Transforms the (Legal) Relationship Between Individuals and Their Personal Records. International Journal of Law and Information Technology, 23, pp.367-368. For empirical studies, see Bradshaw, S., Millard, Ch. and Walden, I. (2011) Contracts for Clouds: Comparison and Analysis of the Terms and Conditions of Cloud Computing Services. International Journal of Information Technology and Law, 19 (3), pp. 198-199.

22 Microsoft. (2020) Microsoft Office Locations Around the World. [online] Available from: https://www.microsoft.com/en-us/worldwide.aspx [Accessed 13 January 2020].

23 Google. (2019) Our Offices. [online] Google. Available from: https://about.google/locations/? region=europe [Accessed 13 January 2020].

24 Spotify. (2020) About Us. [online] Available from: https://www.spotify.com/about-us/contact [Accessed 13 January 2020].

25 Dropbox. (2019) Join Us Around the World. [online] Available from: https://www.dropbox. com/jobs/locations [Accessed 13 January 2020]. 


\section{DIRECTING THE PROFESSIONAL'S ACTIVITIES}

\subsection{THE SIGNIFICANCE OF THE PROFESSIONAL'S INTENTION} In accordance with Article 6(1)(b) of Regulation 593/2008, the law of the country in which the consumer is domiciled governs the contract if the professional, by any means, directs his or her activities to that country. The provision is particularly important for cloud computing contracts, since the provider does not have to establish an office in a Member State to allow the consumer to access the cloud. The ubiquity of that IT solution facilitates offering computing resources to consumers having their habitual residence in countries other than the one in which the provider pursues his or her activities. As a result, it is claimed that Article 6(1)(b) of Regulation 593/2008 often determines the law applicable to the discussed contracts. ${ }^{26}$ Without questioning this conclusion, in my opinion, it is necessary to provide a more in-depth analysis of the applicability of Article 6(1)(b) of Regulation $593 / 2008$ to cloud computing contracts.

The above provision refers to the concept of directed activities. However, Regulation 593/2008 does not explain how to verify whether the activities are "directed" to the country where the consumer is domiciled. The Regulation only specifies that the activities should be of a commercial or professional nature. Consequently, the key element determining the scope of Article 6(1)(b) of Regulation 593/2008 remains unclear. This uncertainty may easily translate into practical concerns. In particular, it could be argued that the provision applies to any situation in which the information of contractual significance (offer, invitation to treat, advertisement, etc.) is placed in a way accessible to the consumer. The indication that the activities can be directed "by any means" seems to additionally support the broad understanding of Article 6(1)(b) of Regulation 593/2008. Similarly, the purpose of the provision, i.e. the improvement of consumer protection, only strengthens this argument.

However, such a broad interpretation would subject almost all contracts concluded over the Internet to Article 6(1)(b) of Regulation 593/2008. This

${ }^{26}$ Bradshaw, S., Millard, Ch. and Walden, I. (2011) Contracts for Clouds: Comparison and Analysis of the Terms and Conditions of Cloud Computing Services. International Journal of Information Technology and Law, 19 (3), p. 198; Castro, C., Reed, Ch. and de Queiroz, R. (2013) On the Applicability of the Common European Sales Law to some Models of Cloud Computing Services. European Journal of Law and Technology, 4 (3). Available from: http://ejlt. org/article/view/186/409 [Accessed 13 January 2020]. 
would certainly be the case in cloud computing contracts, since providers often present contractual information on their websites. More importantly, the provision would apply even if the professional does not intend to conclude contracts with consumers domiciled in a specific country. Such an interpretation could often be detrimental to professionals who would not be able to predict the law applicable to the contract.

Nevertheless, the lack of explanation of the concept of directed activities is not without reason. Instead of defining the term, Recital 24 of Regulation 593/2008 refers in this regard to Article 15(1)(c) of Regulation 44/2001 which was replaced by Article 17(1)(c) of Regulation 1215/2012. Regulation $593 / 2008$ thereby aims to maintain harmony with the provisions on jurisdiction. Yet, even the reference to the provisions of Regulations 44/2001 and 1215/2012 does not dispel all doubts. None of the Regulations explains how to verify whether the professional directs his or her activities to the country where the consumer is domiciled. The gap is, however, filled by the interpretation of Article 15(1)(c) of Regulation 44/2001 by the Court of Justice of the European Union. ${ }^{27}$ According to the judgment, the concept of directed activities only covers situations in which the professional intended to conclude the contract in the country where the consumer has his or her habitual residence. The stance is based on the comparison of Article 13(3) of Brussels Convention ${ }^{28}$ and its successor, i.e. Article 15(1)(c) of Regulation $44 / 2001 .^{29}$

Although this position is well-founded, it inevitably leads to the question of how to determine the intention of the professional. The issue may raise serious practical concerns since analysing people's motivation is often associated with difficulties. In particular, the intention of the professional can usually be verified only on the basis of inference, i.e. by considering the circumstances surrounding the conclusion of the contract. Therefore, it is worth noting that the Court of Justice of the European Union provided a list of factors which can be used to determine whether the professional intended to enter into contracts with consumers domiciled in a specific country. The factors can be divided into

\footnotetext{
${ }^{27}$ Hotel Alpenhof (2010), C-585/08 and C-144/09, EU:C:2010:740, paragraphs 65-69 and 74-76, 7 December.

28 Brussels Convention on jurisdiction and the enforcement of judgments in civil and commercial matters, 1968, (1972/L 299/32). Available from: https://curia.europa.eu/common/recdoc/ convention/en/c-textes/brux.htm [Accessed 13 January 2020].

29 Hotel Alpenhof (2010), C-585/08 and C-144/09, EU:C:2010:740, paragraph 57, 7 December.
} 
positive and negative. The former can further be divided into explicit (i.e. confirming that the professional intended to conclude contracts with consumers domiciled in a certain country) and implicit (i.e. only suggesting such an intention). A relatively large number of factors may not only offer valuable guidelines, but also force parties or the court to weigh potentially conflicting hints. ${ }^{30}$ Consequently, it should be considered if the factors support the application of Article 6(1)(b) of Regulation 593/2008 to cloud computing contracts.

\subsection{EXPLICIT POSITIVE FACTORS}

According to the Court of Justice of the European Union, Article 6(1)(b) of Regulation 593/2008 applies if the professional clearly indicates that they offers goods or services in a specific country. ${ }^{31}$ This comment is useful for cloud computing contracts because sometimes providers explicitly name the countries where they offer access to the cloud. For instance, Spotify and Microsoft created such a list. ${ }^{32}$ Nevertheless, identifying the above factor may not always be an easy task. The providers often do not state that they want to enter into contracts with consumers domiciled in a certain country. For instance, Google refers to broadly understood "[c]ustomer [who] has a billing address in the $E U, "$ thereby not indicating the country by name. ${ }^{33}$ However, sometimes the terms of service may indirectly point to a specific country or a group of countries. For example, the Dropbox Terms of Service refer to the European Union several times, mostly in the context of consumer protection (i.e. the right of withdrawal, the prorogation of jurisdiction and the applicable law). ${ }^{34}$ A similar provision is also stipulated in the Facebook Terms of Service. ${ }^{35}$

Therefore, the question arises whether such information clearly indicates that the provider envisaged doing business with consumers who have their

${ }^{30}$ Bogdan, M. (2011) Website Accessibility as Basis for Jurisdiction under the Brussels I Regulation. Masaryk University Journal of Law and Technology, 5 (1), p. 8.

31 Hotel Alpenhof (2010), C-585/08 and C-144/09, EU:C:2010:740, paragraph 81, 7 December.

32 Microsoft. (2019) Microsoft Cloud Agreements by Region and Language. [online] Available from: https://docs.microsoft.com/en-us/partner-center/agreements [Accessed 13 January 2020]; Spotify. (2019) Spotify Terms and Conditions of Use. [online] Available from: https://www.spotify.com/legal/end-user-agreement/ [Accessed 13 January 2020].

33 Google. (2019) Google Cloud Platform Terms of Service. [online] Available from: https://cloud. google.com/terms/ [Accessed 13 January 2020].

34 Dropbox. (2019) Dropbox Terms of Service. [online] Dropbox. Available from: https://www.dropbox.com/terms?view_en\#terms [Accessed 13 January 2020].

35 Facebook. (2019) Terms of Service. [online] Facebook. Available from: https://www.facebook. com/legal/terms [Accessed 13 January 2020]. 
habitual residence in a specific country. In my opinion, the answer requires careful consideration not only of the quantity, but also of the quality of the information given by the provider. In particular, the intention to conclude the contract with the consumer domiciled in a Member State may manifest by referring to the matters of consumer protection, e.g. the provisions which cannot be derogated by agreement, the right of withdrawal or the rights available in the event of the provider's non-performance. From this perspective, it can be argued that the above information sufficiently demonstrates the intention required under Article 6(1)(b) of Regulation 593/2008. Yet, even if the information cannot be regarded as a clear declaration of intention to do business in a specific country, it may still be classified as a positive indirect factor. Consequently, the information is not devoid of significance. In combination with other factors, it may justify the application of Article 6(1)(b) of Regulation $593 / 2008$.

It should also be noted that the provider may explicitly limit directing his or her activities only to a specific country or a group of countries. Currently, this model is not widely adopted by the providers operating mainly on the public cloud market. However, granting access to the cloud only to selected users is typical for private clouds. ${ }^{36}$ Therefore, it can be assumed that Article 6(1)(b) of Regulation 593/2008 generally does not apply to contracts concerning private clouds, although the conclusion should be drawn after case-by-case analysis. ${ }^{37}$

Furthermore, the contract is governed by the law of the country where the consumer has his or her habitual residence if the professional invests in referencing services to attract the consumers domiciled in a particular country. ${ }^{38}$ It can be expected that this requirement is usually met for large companies offering access to the cloud. For example, displaying the provider's website as the first search result with an indication that the result is an advertisement may confirm the use of the above service.

\footnotetext{
36 Mell, P. and Grance, T. (2011) The NIST Definition of Cloud Computing. Recommendations of the National Institute of Standards and Technology. [online] Gaithersburg: National Institute of Standards and Technology. Available from: https://nvlpubs.nist.gov/nistpubs/Legacy/SP/ nistspecialpublication800-145.pdf [Accessed 13 January 2020].

37 Haibach, G. (2015) Cloud computing and European Union private international law. Journal of Private International Law, 11 (2), p. 263.

38 Hotel Alpenhof (2010), C-585/08 and C-144/09, EU:C:2010:740, paragraph 81, 7 December.
} 


\subsection{IMPLICIT POSITIVE FACTORS}

The intention to enter into contracts with consumers domiciled in a certain country can be indirectly demonstrated by undertaking activities which by their nature are international. ${ }^{39}$ At first glance, the factor appears to be particularly useful for cloud computing contracts. The ubiquity of cloud computing almost implies the international nature of these agreements. The general description seems to further support the application of this factor to cloud computing contracts. Consequently, it is claimed that the factor is often present in the case of these agreements due to their global nature. $^{40}$

In my opinion, however, it should be emphasized that the provider may not take advantage of the potential of clouds to undertake international activities. The provider may simply choose to do business only with consumers who have their habitual residence in the country of the provider's establishment. Therefore, the use of cloud computing as such does not demonstrate the intention required under Article 6(1)(b) of Regulation 593/2008. Rather, it is necessary to consider the type of activities undertaken by the provider, not the IT solution used to perform these activities. It is worth noting that the Court of Justice of the European Union pointed to certain tourist activities, not to the website or the Internet, as an example of activities of international nature. ${ }^{41}$ Therefore, the cloud storage may manifest the intention if the provider declares that the files are accessible in any Member State or may not demonstrate that intention if the provider states that the files are accessible only in the country of his or her establishment.

Moreover, the contract may be governed by the law of the country where the consumer is domiciled if the professional mentions phone number with the international code or uses a top-level domain name specific to the country other than the one in which they is established (e.g. the professional uses domain with ".de" suffix, although they operates in Sweden). ${ }^{42}$ This also includes neutral top-level domain names (e.g. ".com" or ".eu”).

39 Hotel Alpenhof (2010), C-585/08 and C-144/09, EU:C:2010:740, paragraph 83, 7 December.

40 Haibach, G. (2015) Cloud computing and European Union private international law. Journal of Private International Law, 11 (2), p. 263.

${ }^{41}$ Hotel Alpenhof (2010), C-585/08 and C-144/09, EU:C:2010:740, paragraph 83, 7 December.

42 Ibid. Similarly with the reference to phone number, see Emrek (2013), C-218/12, EU:C:2013: 666, paragraph 30, 17 October. 
The reference to a phone number may not offer valuable insight for cloud computing contracts because the providers do not always specify such a number. Instead, they may allow the users to enter the chat, which can be seen as a substitute for phone calls, ${ }^{43}$ send an e-mail, or post a message on Twitter or community forum. ${ }^{44}$ These means of communication as such do not provide information about the intention to do business in a specific country. In particular, the intention required under Article 6(1)(b) of Regulation 593/2008 cannot be determined solely based on the e-mail or geographical address of the professional or his or her intermediary. ${ }^{45}$ However, the indication of the means of communication can be analysed together with other circumstances. For example, offering a chat in Spanish by the provider established in Ireland may indicate that they intended to enter into contracts with consumers domiciled in Spain.

On the other hand, the top-level domain name can be a source of information as to whether the provider envisaged doing business in a Member State. This stems from the fact that providers often use multiple top-level domain names to attract consumers from various countries. For example, Facebook controls many top-level domain names which are prefixed by a language indicator and suffixed by a general name ".com". ${ }^{46}$ Similarly, the last part of Microsoft top-level domain names consists of a language indicator. ${ }^{47}$ Therefore, the activities of such providers can be regarded as directed to consumers having their habitual residence in the country covered by the language indicator. This conclusion is further supported if the website available under such domain name contains information in a corresponding language.

The professional's intention necessary to trigger the application of Article 6(1)(b) of Regulation 593/2008 can also manifest by the language in which contractual information is presented to the consumer or the currency in which the contract is paid. However, this factor is only

$\overline{43}$ Bundesverband (2008), C-298/07, EU:C:2008:572, 16 October.

44 See e.g. Dropbox. (2020) Contact Dropbox Support. [online] Dropbox. Available from: https://www.dropbox.com/support [Accessed 13 January 2020].

45 Hotel Alpenhof (2010), C-585/08 and C-144/09, EU:C:2010:740, paragraphs 77, 91, and 94, 7 December.

46 The list of language indicators is available as a switch at the bottom of the website, see Facebook. (2020) Facebook. [online] Facebook. Available from: https://www.facebook.com/ [Accessed 13 January 2020].

47 The list of language indicators is available as a switch at the bottom of the website, see Microsoft. (2020) Microsoft. [online] Available from: https://onedrive.live.com/about/en-gb/ [Accessed 13 January 2020]. 
relevant if the language or the currency is different than the one usually used in the country where the professional is established. ${ }^{48}$ The reservation does not undermine the usefulness of that factor for cloud computing contracts. To attract users, the providers often present the information on the website in the language used in the visitor's country. It is thus not uncommon to offer multiple translations. For example, the Dropbox website is available in 22 language versions, ${ }^{49}$ the Microsoft - in $93,^{50}$ while the Facebook - in $110 .^{51}$ Moreover, providers are usually established in countries where the official language is English (i.e. they focus their activities mainly in the USA, the UK and Ireland). Therefore, the presentation of contractual information in other languages used in the country where the consumer is domiciled may demonstrate the intention required under Article 6(1)(b) of Regulation 593/2008.

Furthermore, the law of the country of consumer's habitual residence may apply to the contract if the professional indicates that his or her customers compose of people domiciled in various countries, particularly if the professional presents accounts of such customers. ${ }^{52}$ According to some scholars, this factor is often present in the case of cloud computing contracts. ${ }^{53}$ In my opinion, however, the factor may not always be useful because not all providers emphasize concluding contracts with customers from different countries or collect their feedback. Nevertheless, at least some providers adopt such a business model (e.g. providers of social media or booking services). Therefore, the factor may offer valuable information as to whether the provider intended to enter into contracts with consumers domiciled in a specific country.

Finally, the Court of Justice of the European Union decided that the causal link between the presentation of information on the professional's website and the conclusion of the contract is not necessary for the application of Article 6(1)(b) of Regulation 593/2008. ${ }^{54}$ The link may, however,

48 Hotel Alpenhof (2010), C-585/08 and C-144/09, EU:C:2010:740, paragraph 84, 7 December.

49 Dropbox. Main page. [online] Available from: https://www.dropbox.com [Accessed 13 January 2020].

${ }_{50}$ Microsoft. (2020) Microsoft. [online] Available from: https://onedrive.live.com/about/en-gb/ [Accessed 13 January 2020].

51 Facebook. (2020) Facebook. [online] Facebook. Available from: https://www.facebook.com/ [Accessed 13 January 2020].

52 Hotel Alpenhof (2010), C-585/08 and C-144/09, EU:C:2010:740, paragraph 83, 7 December.

53 Haibach, G. (2015) Cloud computing and European Union private international law. Journal of Private International Law, 11 (2), p. 263.

54 Emrek (2013), C-218/12, EU:C:2013:666, paragraphs 26 and 29, 17 October. 
demonstrate that the professional envisaged doing business in the country where the consumer has his or her habitual residence. This comment may also apply to cloud computing contracts. However, the factor should not be overemphasized, because the causal link is often present in the case of these agreements. The consumer usually enters into cloud computing contracts by using electronic means of communications. In contrast, the consumer rarely concludes such contracts in other forms, particularly in writing.

\subsection{NEGATIVE FACTORS}

The Court of Justice of the European Union also formulated a list of factors that do not substantiate the application of Article 15(1)(c) of Regulation 44/2001. The list may also be used for Article 6(1)(b) of Regulation 593/2008. Consequently, it should be noted that mere access to the professional's website is insufficient to assume that the provider intended to do business in the country where the consumer is domiciled. ${ }^{55}$ This includes "interactive" websites, i.e. pages which allow the parties to enter into a contract only by using electronic means of communication. ${ }^{56}$ Similarly, the marketing of goods or services supplied over the Internet, as such, does not result in the application of Article 6(1)(b) of Regulation 593/2008. ${ }^{57}$ These comments are relevant for cloud computing contracts which are not only concluded, but also perform using electronic means of communication, especially websites. Therefore, plain access to the website does manifest the provider's intention to direct the activities to the country where the consumer has his or her habitual residence.

Furthermore, mandatory information presented on the professional's website is also insufficient to determine his or her intention regarding doing business in the country of the consumer's domicile. ${ }^{58}$ This factor is also important for cloud computing contracts. It should be noted that consumer protection in the European Union is based on the assumption that the consumer is the weaker party because he or she does not have the same information as the professional. Therefore, European law aims to eliminate the information asymmetry by imposing extensive information obligations on the professional. These obligations are particularly important in the case

\footnotetext{
55 Hotel Alpenhof (2010), C-585/08 and C-144/09, EU:C:2010:740, paragraphs 74 and 94. See Recital 24 of Regulation 593/2008, 7 December.

56 Hotel Alpenhof (2010), C-585/08 and C-144/09, EU:C:2010:740, paragraph 79, 7 December.

57 Hotel Alpenhof (2010), C-585/08 and C-144/09, EU:C:2010:740, paragraph 73, 7 December.

58 Hotel Alpenhof (2010), C-585/08 and C-144/09, EU:C:2010:740, paragraph 78, 7 December.
} 
of cloud computing contracts which are subject not only to Directive $2000 / 31{ }^{59}$ but also to Directive $2011 / 83^{60}$ and soon - to Directive 2019/770 ${ }^{61}$ As a result, it can be expected that the provider is required to present a considerable amount of information to the consumer. However, this information cannot be used as a decisive argument when determining the provider's intention regarding the country where the provider intended to do business.

\section{CONCLUSION}

The ubiquity of cloud computing facilitates entering into contracts with consumers from various countries. Consequently, the question of the law applicable to these agreements may often arise, especially if the contract is concluded between a consumer and a professional. The considerations presented in this article confirm that the current legal framework is sufficient for consumer protection. Contrary to concerns raised by some scholars, it can be assumed that the law of the country where the consumer is domiciled will often govern at least some obligations arising from cloud computing contracts. However, the application of Article 6 of Regulation $593 / 2008$ may not always be free from doubts. In particular, the analysis indicates that the factors previously considered relevant may not offer valuable information about the provider's intention to enter into contracts with consumers domiciled in a specific country. Instead, other factors highlighted by the Court of Justice of the European Union may help clarify this issue. To determine the law applicable to cloud contracts concluded with consumers, the quality rather than the quantity of information presented by the provider should be taken into account. As a result, the intention of the provider to direct their professional activities to a specific Member

59 Directive 2000/31/EC of the European Parliament and of the Council of 8 June 2000 on certain legal aspects of information society services, in particular electronic commerce, in the Internal Market ('Directive on electronic commerce'). Official Journal of the European Communities (2000/L-178/1), 17 July. Available from: http://data.europa.eu/eli/dir/2000/31/oj [Accessed 13 January 2020].

60 Directive 2011/83/EU of the European Parliament and of the Council of 25 October 2011 on consumer rights, amending Council Directive 93/13/EEC and Directive 1999/44/EC of the European Parliament and of the Council and repealing Council Directive 85/577/EEC and Directive 97/7/EC of the European Parliament and of the Council. Official Journal of the European Union (2011/L-304/64), 22 November. Available from: http://data.europa.eu/ eli/dir/2011/83/2018-07-01 [Accessed 13 January 2020].

61 Directive (EU) 2019/770 of the European Parliament and of the Council of 20 May 2019 on certain aspects concerning contracts for the supply of digital content and digital services. Official Journal of the European Union (2019/L-136/1), 22 May. Available from: http://data. europa.eu/eli/dir/2019/770/oj [Accessed 13 January 2020]. 
State may be indicated in particular by a high level of detail of the information given to the consumer, the language of the information, methods of communication with the consumer or the name of the top-level domain.

\section{LIST OF REFERENCES}

[1] Andrews, C.D. and Newman, J.M. (2013) Personal Jurisdiction and Choice of Law in the Cloud. Maryland Law Review, 73

[2] Bogdan, M. (2011) Website Accessibility as Basis for Jurisdiction under the Brussels I Regulation. Masaryk University Journal of Law and Technology, 5 (1)

[3] Bradshaw, S., Millard, Ch. and Walden, I. (2011) Contracts for Clouds: Comparison and Analysis of the Terms and Conditions of Cloud Computing Services. International Journal of Information Technology and Law, 19 (3).

[4] Brussels Convention on jurisdiction and the enforcement of judgments in civil and commercial matters, 1968, (1972/L 299/32). Available from: https://curia.europa.eu/common/recdoc/ convention/en/c-textes/brux.htm [Accessed 13 January 2020].

[5] Castro, C., Reed, Ch. and de Queiroz, R. (2013) On the Applicability of the Common European Sales Law to some Models of Cloud Computing Services. European Journal of Law and Technology, 4 (3). Available from: http://ejlt.org/article/view/186/409

[Accessed 13 January 2020].

[6] Celestine, C.M. (2013) "Cloudy" Skies, Bright Futures? In Defense of a Private Regulatory Scheme for Policing Cloud Computing. Journal of Law, Technology E Policy, 1.

[7] Council Directive 93/13/EEC of 5 April 1993 on unfair terms in consumer contracts. Official Journal of the European Communities (1993/95-L-29), 21 April. Available from: http://data.europa.eu/eli/dir/1993/13/oj [Accessed 13 January 2020].

[8] Council Regulation (EC) No 44/2001 of 22 December 2000 on jurisdiction and the recognition and enforcement of judgments in civil and commercial matters. Official Journal of the European Union (2001/12-L/1), 16 January. Available from: http://data. europa.eu/eli/reg/2001/44/oj [Accessed 13 January 2020].

[9] De Filippi, P. and McCarthy, S. (2012) Cloud Computing: Centralization and Data Sovereignty. European Journal of Law and Technology, 3 (2). Available from: http://ejlt.org/ article/view/101 [Accessed 13 January 2020]. 
[10] De Filippi, P. and Belli, L. (2012) Law of the Cloud v Law of the Land: Challenges and Opportunities for Innovation. European Journal of Law and Technology, 3 (2). Available from: http://ejlt.org/article/view/156 [Accessed 13 January 2020].

[11] Directive 2000/31/EC of the European Parliament and of the Council of 8 June 2000 on certain legal aspects of information society services, in particular electronic commerce, in the Internal Market ('Directive on electronic commerce'). Official Journal of the European Communities (2000/L-178/1), 17 July. Available from: http://data.europa.eu/eli/dir/2000/ 31/oj [Accessed 13 January 2020].

[12] Directive 2011/83/EU of the European Parliament and of the Council of 25 October 2011 on consumer rights, amending Council Directive 93/13/EEC and Directive 1999/44/EC of the European Parliament and of the Council and repealing Council Directive 85/577/EEC and Directive 97/7/EC of the European Parliament and of the Council. Official Journal of the European Union (2011/L-304/64), 22 November. Available from: http://data.europa.eu/eli/dir/2011/83/2018-07-01 [Accessed 13 January 2020].

[13] Directive (EU) 2019/770 of the European Parliament and of the Council of 20 May 2019 on certain aspects concerning contracts for the supply of digital content and digital services. Official Journal of the European Union (2019/L-136/1), 22 May. Available from: http://data.europa.eu/eli/dir/2019/770/oj [Accessed 13 January 2020].

[14] Dropbox. Main page. [online] Available from: https://www.dropbox.com [Accessed 13 January 2020].

[15] Dropbox. (2019) Dropbox Terms of Service. [online] Dropbox. Available from: https://www.dropbox.com/terms?view_en\#terms [Accessed 13 January 2020].

[16] Dropbox. (2019) Join Us Around the World. [online] Available from: https://www.dropbox. com/jobs/locations [Accessed 13 January 2020].

[17] Dropbox. (2020) Contact Dropbox Support. [online] Dropbox. Available from: https://www.dropbox.com/support [Accessed 13 January 2020].

[18] Facebook. (2019) Terms of Service. [online] Facebook. Available from: https://www.facebook.com/legal/terms [Accessed 13 January 2020].

[19] Facebook. (2020) Facebook. [online] Facebook. Available from: https://www.facebook.com [Accessed 13 January 2020].

[20] Google. (2019) Google Cloud Platform Terms of Service. [online] Available from: https://cloud.google.com/terms/ [Accessed 13 January 2020].

[21] Haibach, G. (2015) Cloud computing and European Union private international law. Journal of Private International Law, 11 (2). 
[22] Irion, K. (2015) Your Digital Home is No Longer Your Castle: How Cloud Computing Transforms the (Legal) Relationship Between Individuals and Their Personal Records. International Journal of Law and Information Technology, 23.

[23] Judgment of 16 October 2008, Bundesverband, C-298/07, EU:C:2008:572.

[24] Judgment of 14 May 2009, Ilsinger, C-180/06, EU:C:2009:303.

[25] Judgment of 7 December 2010, Hotel Alpenhof, C-585/08 and C-144/09, EU:C:2010:740.

[26] Judgment of 6 September 2012, C-190/11, Mühlleitner, EU:C:2012:542.

[27] Judgment of 14 March 2013, Česká spořitelna, C-419/11, EU:C:2013:165.

[28] Judgment of 17 October 2013, Emrek, C-218/12, EU:C:2013:666.

[29] Judgment of 28 January 2015, Kolassa, C-375/13, EU:C:2015:37.

[30] Judgment of 25 January 2018, Schrems, C-498/16, EU:C:2018:37.

[31] McGillivray, K. (2016) A Right Too Far? Requiring Cloud Service Providers to Deliver Adequate Data Security to Consumers. International Journal of Law and Information Technology, 25.

[32] Mell, P. and Grance, T. (2011) The NIST Definition of Cloud Computing. Recommendations of the National Institute of Standards and Technology. [online] Gaithersburg: National Institute of Standards and Technology. Available from: https://nvlpubs.nist.gov/nist pubs/Legacy/SP/nistspecialpublication800-145.pdf [Accessed 13 January 2020].

[33] Microsoft. (2019) Microsoft Cloud Agreements by Region and Language. [online] Available from: https://docs.microsoft.com/en-us/partner-center/agreements [Accessed 13 January 2020].

[34] Microsoft. (2020) Microsoft Office Locations Around the World. [online] Available from: https://www.microsoft.com/en-us/worldwide.aspx [Accessed 13 January 2020].

[35] Microsoft. (2020) Microsoft. [online] Available from: https://onedrive.live.com/about/en$\mathrm{gb} /$ [Accessed 13 January 2020].

[36] Regulation (EC) No 593/2008 of the European Parliament and of the Council of 17 June 2008 on the law applicable to contractual obligations (Rome I). Official Journal of the European Union (2008/177-L/6), 4 July. Available from: http://data.europa.eu/eli/reg/ 2008/593/oj [Accessed 13 January 2020].

[37] Regulation (EU) No 1215/2012 of the European Parliament and of the Council of 12 December 2012 on jurisdiction and the recognition and enforcement of judgments in civil and commercial matters (recast). Official Journal of the European Union (2012/351-L/1), 20 December. Available from: http://data.europa.eu/eli/reg/2012/1215/2015-02-26 [Accessed 13 January 2020]. 
[38] Rustad, M.L. and Onufario, M.V. (2012) Reconceptualizing Consumer Terms of Use for a Globalized Knowledge Economy. University of Pennsylvania Journal of Business Law, $14(4)$.

[39] Spotify. (2019) Spotify Terms and Conditions of Use. [online] Available from: https://www.spotify.com/legal/end-user-agreement/ [Accessed 13 January 2020].

[40] Spotify. (2020) About Us. [online] Available from: https://www.spotify.com/about-us/ contact/ [Accessed 13 January 2020].

[41] Wauters, E., Lievens, E. and Valcke, P. (2014) Towards a Better Protection of Social Media Users: a Legal Perspective on the Terms of Use of Social Networking Sites. International Journal of Law and Information Technology, 22. 